Vol. 3, No. 2, 2016

UDC 657.421.3:658.011

M. Plekan

$\mathrm{PhD}$, Senior Lecturer

Lviv Polytechnic National University

\title{
ACCOUNTING FOR AN INTANGIBLE COMPONENT OF A TRADING COMPANY'S EQUITY CAPITAL
}

\begin{abstract}
The economic nature of intangible assets as components of trading company's equity capital is disclosed. Theoretical and methodological provisions of intangible assets accounting are analyzed and the existing problematic aspects of reflecting these objects in the accounting system and financial reporting are presented. There are proposed some aspects of improving methodology of accounting intangible assets in their interrelation with the value of the trading company's capital.
\end{abstract}

Keywords: accounting, intangible assets, capital components, internally generated intangible objects, intellectual capital, methodology.

\section{Introduction}

Significant changes of views on the productive power of capital of a post-industrial company, the growing importance of intangible economic resources in its effective functioning and the importance of public representation of this type of economic potential require an appropriate adaptation of the accounting system. Accounting and public financial reporting are an essential function of the management system, the effectiveness of which at present is determined by the cost criteria, they being the estimated parameters of the equity market value, in the structure of which an intangible component has significant value.

Information and intellectual components such as brand, trademark, goodwill, organizational structure and so on are of great importance in evaluating the entity capital (market value) of trading companies, especially shopping complexes of a network type. This type of the company's economic resources "in certain circumstances, may be considered as the result of intellectual activity, which implies that their evaluation can be attributed to intangible assets" [1, p. 67]. This very need to represent such type of economic resources in the reporting of a commercial enterprise is clearly expressed and implies the necessity to transform the existing accounting system, the content aspects of which should be directed towards changing ideology and norms of accounting, its functional role in the management of a trade enterprise.

The current system of accounting and financial reporting fails to reflect intangible assets and intellectual capital. In terms of formalization and reflection in accounting, the objects of internally generated intangible assets of any enterprise, in particular, a trading company, being the most difficult to identify and evaluate, are the most problematic. For a number of objective reasons (problematic evaluation, criteria for recognition of assets as the objects of accounting), very often they do not become the objects of accounting and are not recorded as assets at all. Since the value-estimated assets characterize the total value of equity capital, it is clear that in the accounting system the entity capital of commercial enterprises is presented at a lower cost. This fact greatly affects the efficiency of the capital management and the characteristics of business reputation of domestic trading companies.

\section{Analysis of recent research and publications.} The issues of objective representation of the modern enterprise total capital value with formalized, reliable indicators in public reporting are widely discussed in the world economic science and find various practical appraisals. The main focus of the problem lies in the formation of reliable formalized information on information and intellectual component of the company's capital in the accounting system. The basic idea leading to solution of this problem is associated with the improvement of accounting of intangible assets. Some scientists, I. Yo. Yaremko, in particular, directly link the completeness of intangible assets 


\section{Plekan}

reflection in accounting with the evaluation of the company's capital, stating that "intangible assets are a form of "representation" of intellectual capital" [2, p. 27].

Both scholars and practitioners have common opinion that the availability of only one type of information about financial and material resources extremely complicates the possibility of providing the cost characteristics of the capital of modern enterprises. In the subject area of knowledge this view is recognized. Thus, for example, N.O. Vlasova argues that "the use of information exclusively about financial sources of capital in calculations distorts the real conditions of commercial enterprises" [3].

In general, the topics discussed are considered the least developed in the world economic theory and practice. In particular, scientists [4] indicate that deep and comprehensive theoretical research in this field with a comprehensive analysis of both domestic and international accounting practice are rare ... insufficient attention is paid to improving the methodology of accounting for intangible assets. According to many scientists, the root of the problem is in the possibility to reflect internally generated intangible assets in the accounting system. A. P. Ivanov and Ye. M. Bunina considering the reputation of the modern company as immaterial component of productive power of its capital, note that "qualification and attributes of business reputation as an intangible asset are different as to the difficulty of estimating the object of accounting, the need for a thorough justification of the criteria of referring this asset to intangible assets" [1, p. 69].

The aim of this article is to analyze the developments on the issues under consideration, to research into the direction of the paradigms offered, to systematize them and formulate certain aspects concerning more coverage of intangible objects as a component of commercial enterprise capital by the accounting system.

Presentation of the main material. The concept of capital components as well as points of view on the capital cost parameters are changing together with civilization development of scientific and technical progress, conditions of business management and, as a result, production of new evaluation criteria of the potential of current functioning and long-term development of modern trade enterprise. The importance of information and intellectual components in the capital of the modern market entities is great. As an example," business reputation is an important factor of strengthening the enterprise positions in terms of its stable development, since it ensures gaining additional competitive advantages on the markets of capital, resources, securities etc. [1, p. 67].

In the concepts and paradigms of postindustrial society economic resources of such type (information, knowledge) are recognized as the basic factors of competitiveness, investment attractiveness and long-term development potential. Scientists and practitioners are of the opinion that in the last years more intensively "there is beginning to form a new paradigm of influence of the role of intangible assets in the growth of the companies' value" [5, p. 11]. The tendencies of increasing the capital by the companies at the expense of intangible components are quite obvious from the analytical reviews of stock markets. That is why the formalized disclosure of information about such type of potential is essential for national economy trading companies, which operate in conditions of global competition.

Based on the economic nature (economic matter) and the nature of intangible assets we can assert the existence of direct relationship between their cost and the cost of the total capital of the enterprise, in particular, its intellectual component. Arguments that the "intellectual capital" is a term for intangible assets are quite common and clear [6, p. 37]. Although it is believed that "the emergence of the concept of "intellectual capital" in the scientific community in most cases was caused by the need to refer to those intangible assets that the market accepted, but accounting did not recognize" [7, p. 15]. This resulted in significant differences between the book and market value of postindustrial companies' equity.

The need to develop a new approach to consider the essence of intangible objects in the system of accounting and financial reporting is obvious, given the dominance of value criteria in assessing the effectiveness (increase of the company's value) and potential (productive power of the capital) of the modern market economy entities. It primarily concerns the issues of 
formalized extension of the list of intangible assets, including objects created by the companies themselves (internally generated intangible economic resources). In terms of the definition of the objects of accounting "the biggest problem that arises during identification of an intangible asset is determining its differences from the goodwill. An intangible asset can be distinguished from goodwill only in case the company can sell, rent or exchange it" [4, p. 152].

The improved methodology of the intangible assets accounting should be oriented towards more extensive coordinates of considering intangible economic resources, arranging the process of their integral reflection in the accounting system. The methodology of accounting system that is adaptive to the information and knowledge economy should first of all solve the problem of identification and objective evaluation of the internally generated intangible objects. These assets are mainly directed to the identification and individualization of a particular enterprise (product), namely those which in marketing literature are associated with the term "brand" or economic "goodwill". In analytical reviews, the term "brand" is defined as "a trademark, which in the eyes of the consumer possesses clear and meaningful set of values and attributes" [8].

For such objects to be introduced into the accounting system, the determining factor is the possibility to measure their value, i.e. to have methodology for determining their value as of an economic resource in the relevant market segment. Despite the complexity of such an evaluation, "ability to display brand in the accounting system will reduce the gap between the market and the book value of companies" [7, p. 83]. Representation of the internally generated intangible assets, such as "goodwill", is the identical problem. The existing problems are confirmed by the fact that "developed concepts of the methods of evaluation and accounting of goodwill have passed several stages of modernization ... there are different options for its reflection in accounting: as an intangible asset, as a change in the capital, as expenses of the reporting period, positioning in other assets" [9, p. 28, 29].

Intangible economic resources of modern enterprises are very diverse, that is why sometimes they are articulated by substandard assets. For example, "the category "business reputation" is often equated with "goodwill" as it reveals essentially similar characteristics, features and value of these concepts" [1, p. 67]. In some cases, such objects may have the documented rights of ownership of them and the value recorded in the documents of the enterprise; in other cases, they have none of these. The first type of intangible assets of the company is referred to as trademarks, licenses, patents, copyrights and contracts. These intangible resources are recognized as assets because they are "the things owned by somebody" [10, p. 134], the right of ownership being protected by law. Fixing the value of this type of intangible assets in the balance of the company on the basis of documentary evidence of the ownership creates the conditions for their value assessment.

Intangible assets of the second type (the company's reputation, its corporate (organizational) culture, employees' knowledge) have no documentary evidence concerning the right of ownership, which causes the problem as to their fixing in the balance and assessing their value.

The generalized definition of intangible assets as an object of accounting is "assets are the resources controlled by the enterprise as a result of past events, the use of which is expected to lead to obtaining economic benefits in the future". This definition reveals the basis for their recognition as an object of accounting and public financial reporting. In addition, some specific accounting rules of standardization impose other criteria for recognition of intangible assets for the purposes of their introduction into the accounting system: a non-monetary asset that has no physical form can be identified and kept by an enterprise for more than a year. On the basis of these regulations, scientists point out that all these rules being accounted, "it appears that an intangible asset as an enterprise resource can be neither financial capital nor any capital at all" $[11$, p. 116]. However, "the right" itself is not a resource; it is neither capital nor labor or natural resource and therefore it cannot be an asset.

An intellectual product under certain conditions becomes an intellectual property, i.e. there is the fact of emerging property rights. Therefore, it is concluded that the sub-accounts associated with "the acquisition of rights", "are mistakenly included into intangible assets" and all these "extra" objects in intangible assets can be unified in one category, that of "deferred expenses" [11, p. 116]. 
The process of intangible resources evaluation is used for elaborating the strictly reasonable value of intangible assets of a certain category considering all alternative data. The selection of an appropriate value standard has direct influence on the estimated value of the object. The most effective and the best evaluation standard for intangible assets assessment is determined by four criteria: the legal admissibility, physical capacity, financial feasibility and maximum profitability [12]. The evaluation of intangible resources cost is conducted using cost, profitable and market (comparative) approaches.

Conclusions. The efficiency of modern enterprise management in general and the cost of capital as one of the most widely used criteria in modern economy require flexibility of accounting systems. Development and improvement of accounting and public reporting as a tool for management and regulation of the financial and economic processes should be considered in terms of opportunities to reflect and display the formal data about actually existing intangible assets in the company in relation to intellectual capital.

The practical implementation of the offers to display internally generated economic resources (trade name, trademark, reputation etc.) by domestic trading enterprises will contribute to the objectivity of the value characteristics of their potential and will provide formalized data for the processes of enterprise evaluation. Application of the probable concept of the internally generated assets estimation, their reflection in relation to the capital in any form as a part of the public financial reporting is significant for the Ukrainian trade enterprises because it increases their investment attractiveness.

\section{References}

1. Ivanov A. P. Business reputation of the company as immaterial active / A. P. Ivanov, E. M. Bunina // Finance. - 2005. - No. 6. - P. 67-71.
2. Yaremko I. Y. Management of enterprise capital: economic and financial instruments: a monograph / I. Y. Yaremko. - Lviv press : Kameniar, 2006. $176 \mathrm{p}$.

3. Vlasova N. O. Formation of an optimal capital structure in retail trade enterprises / N. O. Vlasova, L. I. Bezginova. - Kharkiv : DDUHT, 2006. - $160 \mathrm{p}$.

4. Didur S. V. Aspects of accounting of intangible assets / S. V. Didur, O. I. Avramenko, N. V. Kurochka // Economy and region. - 2007. No. 1 (12). - P. 150-153.

5. Puzynia N. Yu. Assessment and management of the intangible assets of the company: a monograph / N. Yu. Puzynia. - SPb. : SPbHEU press, 2013. - 179 p.

6. Bruking E. Intellectual capital: scientific publication. / E. Bruking; translation from English. - SPb : Peter, 2001. - 288 p.

7. Kutsyk P.O. The accounting concept of value management of intangible assets of the enterprise: a monograph / P. O. Kutsyk, I. M. Drohobytskyi, Z. P. Plysa. Kh. I. Skop. - Lviv: R-7, 2016. - 268 p.

8. Brazylii N. M. Accounting and audit of intangible assets (on the example of food industry): author's abstract dissertation on the obtaining the degree of candidate of economic sciences; specialization 08.06.04 "Accounting, analysis and audit" / N. M. Brazylii. - K., 2007. - 20 p.

9. Kasych A. O. Theoretical and methodological bases of enterprise goodwill evaluation and accounting / A. O. Kasych // University of Uzhhorod Scientific Journal. Series "Economy". 2015. - Issue 1(45). T. 2. - P. 28-32.

10. Hall $R$. The strategic analysis of intangible resources / R. Hall // Strategic Management Journal. - 1992. - No. 13. - P. 135-144.

11. Proskurina N. M. Problems and the ways of improvement of intangible assets accounting / N. M. Proskurina, V. V. Siomchenko, O. M. Bondarenko // Zaporizhzhia National University Journal. - 2008. - No. 1 (3). - P. 115-119.

12. Zymovets $O$. P. Analysis of native and foreign approaches to the evaluation of intangible resources. / O. P. Zymovets // Lviv Commerce Academy Journal. Economic series. - 2011. Issue 35. - P. 149-152. 
Vol. 3, No. 1, 2016

UDC 331.108:37.031:59.9

I. Sytnyk

Ph.D. of Economics, Associate Professor

Lviv Polytechnic National University

\section{UPDATING MANAGEMENT MODELS IN TERMS OF ENTERPRISE MANAGEMENT INTELLECTUALIZATION}

\begin{abstract}
The article explores the dynamics of the proportion of adult population among the Internet users and the use of information and communication technologies by enterprises in Ukraine. The different impact of digital technologies on economic development of a number of countries is considered. The dynamics of the number of scientific as well as scientific and technical studies in the structure of GDP of Ukraine is analysed. The change of the quantity of industrial enterprises that carry on innovative activity is considered. Peculiarities of the change in volumes of realized innovative products of the Ukrainian enterprises during the period of 2005-2015 are identified. Key risks and reserves of strengthening the intellectualization processes of the enterprise management systems are determined. There are formed priority tasks for management systems of enterprises in conditions of dynamic development of information and communication technologies as well as processes of intellectualization.
\end{abstract}

Keywords: intellectualization, management system, model of management, knowledge, integration, efficiency, innovation.

\section{Formulation of the problem}

The current economic outlook and management paradigm are formed through the prism of the categories of "intelligence", "knowledge economy", "information economy". This leads to the occurrence of such terms of management and economic science as comprehensive globalization, the increasing role of human factors, the commercialization of the Internet, large-scale development of the intellectual potential and capital of enterprises, the use of deep institutional, technological and cultural environment.

At the same time, the current world is experiencing the best opportunities for intellectual growth in space and time due to the largest information and communication revolution in the history of mankind. After all, more than forty percent of the world's population has access to the Internet, and every day in the network there are new users that dynamically expands the boundaries of digital intellectual economy.

So, M. Castells names the modern economy informational and global. Iformational, because the competitiveness of agents in an economy is determined primarily by their ability to collect, process and use information, which is based on knowledge and global - because the principal economic activities are organized on a global scale. Iformational and global efforts for the achievement of a certain level of performance and the existence of competition can only take place within a global network $[1$, c. 81$]$.

$\mathrm{V}$. Heyets believes that in the new economy the decisive factor is the process of accumulation and use of knowledge: "in economy the knowledge is defining the intellectual potential of the society on which it relies and which is a collection of everyday and specialized knowledge." [4, p. 17].

Under such conditions the task of management is to ensure the ability to take advantage of rapid technological change, to overcome the traditional problems of development, to intellectualize management model (management system) and provide the growth of competitiveness.

\section{Analysis of recent research and publications}

Investigation of various aspects of the problem of formation of information economy, impact of information and communication technologies, online tools, personalized knowledge and intangible assets in the determination of competitive advantages of modern economic processes and management of enterprises finds its light in the works of such Ukrainian scientists as L. Fedulova [2], L. Melnik [6], V. Shevchenko [12], N. Shpak [13] and foreign researchers G. Kolodko [3], S. Tesyera and A. Rogera [15], T. Steward [14] and others. However, studies done by researchers insufficiently disclosed the interrelation between implementing the processes of intellectualization at national enterprises, on one hand, and obtaining economic benefits and effective management by these enterprises, on the other hand.

In fact, a study of the latest trends in the field of intellectualization of the economy and their impact on the enterprise management system will enable us to comprehend and summarize the key factors of actualization of management models and the process of formation of intellectual-knowledge assets of enterprises 